\title{
EFEKTIFITAS TRAINER PNEUMATIK SEBAGAI MEDIA PEMBELAJARAN PADA MATERI PENGONTROLAN GERAK SEKUENSIAL
}

\author{
Purnawan \\ Jurusan Pendidikan Teknik Mesin FPTK UPI \\ Jl. Dr. Setiabudhi 207 Bandung 40154 \\ purnawan@upi.edu
}

\begin{abstract}
Abstrak : Tujuan penelitian ini adalah untuk mengetahui efektifitas penggunaan trainer pneumatik hasil pengembangan sebagai media pembelajaran pada materi pengontrolan gerak sekuensial. Penelitian menggunakan metode quasi-eksperimen dengan pre and post test design. Materi dibatasi pada pengontrolan gerak sekuensial menggunakan dua aktuator yang diaplikasikan untuk pemindah benda. Pada kelas kontrol digunakan media pembelajaran training kit sementara pada kelas eksperimen digunakan trainer hasil pengembangan. Tes esay berupa perancangan kontrol dalam bentuk sirkuit diagram untuk aplikasi pemindahan produk elektroplating. Hasil penelitian menunjukkan bahwa trainer pneumatik hasil pengembangan dan training kit cukup efektif sebagai media belajar pada materi pengontrolan gerak sekuensial. Uji statistik menunjukkan tidak ada perbedaan yang signifikan antara dua kelompok, sehingga dapat disimpulkan bahwa trainer pneumatik hasil pengembangan tidak lebih efektif sebagai media belajar dibandingkan dengan training kit.
\end{abstract}

Kata kunci : pneumatik, trainer, training kit, gerak sekuensial

\begin{abstract}
The purpose of this study is to determine the effectiveness of pneumatic trainer as instructional media in sequential motion control material. The research uses quasi-experimental method with pre and post test design. The material is limited to sequential motion control using two actuators for objects transfer. Control class uses instructional media training kit, while experimental class uses development-result trainer. Essay tests are in form of diagram circuit for application of electroplating products transfer. The results show that the developed pneumatic trainer and training kit are quite effective as media of learning in sequential motion control. Statistical tests indicate no significant difference between the two groups, so that it can be concluded that compared to training kit, the developed pneumatic trainer is not more effective as learning media.
\end{abstract}

Keywords: pneumatic, trainers, training kit, sequential motion

\section{PENDAHULUAN}

Sistem pneumatik merupakan suatu sistem kerja yang menggunakan udara terkompresi sebagai media kontrol dan media kerja. Mengacu pada karakteristik alamiah udara, sistem pneumatik memiliki keunggulan diantaranya ketersediaan media yang tanpa batas, murah, bersih, ramah lingkungan, mudah disimpan, mudah ditransportasikan, mempunyai kecepatan yang relatif tinggi, tidak sensitif terhadap perubahan teperatur, dan aman terhadap beban lebih.

Pneumatik sebagai sistem dibangun atas dua konsep utama yaitu konsep stuktur sistem dan konsep mekanisme komponen. Konsep struktur sistem menjelaskan bagaimana siklus fluida berproses dan membangkitkan sinyal 
sehingga membentuk sebuah sistem kerja. Konsep mekanisme komponen menjelaskan sifat-sifat komponen dalam sebuah sistem tersebut yang meliputi; prinsip kerja, metode aktuasi dan pengembaliannya, jumlah posisi kontak yang mungkin terjadi, jumlah saluran input-output dan sebagainya. Penjelasan konsepkonsep tersebut direpresentasikan dalam simbol-simbol verbal yang terstandarisasi (DIN ISO 1219 dan DIN ISO 5599).

Kesulitan memahami konsep yang abstrak, komplek, dan dinamik merupakan permasalahan dalam pembelajaran sistem pneumatik. Berdasarkan hasil penelitian (Purnawan:2006), model teoritis berupa simbol-simbol verbal maupun media/alat bantu pembelajaran yang tersedia, tidak cukup representatif untuk dapat menjelaskan konsep sistem pneumatik secara realistis, sehingga kemungkinan tidak terjangkau (inaccessible) oleh peserta didik yang efeknya kurang menimbulkan pengalaman belajar.

Berdasar paparan tersebut, maka diperlukan media pembelajaran yang tidak hanya dalam tataran teoritis, tetapi media yang praktis, ekonomis, dan mudah dijangkau (accessible) yang mampu mengkonsolidasikan konsep sistem pneumatik di atas. Upaya memenuhi kriteria accessible dapat ditempuh dengan memanipulasi model teoritis (verbal / simbol) menjadi model realistis agar mudah diajarkan (teachable).

Penelitian sebelumnya telah menghasilkan trainer pneumatic yang diaplikasikan pada sistem pemindah benda dua tahap untuk menjelaskan pengontrolan gerak sekuensial. Pada penelitian ini dilakukan uji validasi terhadap produk tersebut dengan membandingkan efektifitasnya sebagai media pembelajaran dengan training kit. Sehingga rumusan permasalahan penelitian adalah apakah penerapan trainer pneumatik lebih efektif dibandingkan dengan training kit sebagai sebagai media pembelajaran pada materi pengontrolan gerak sekuensial ?

Mengacu pada rumusan masalah, maka tujuan penelitian ini adalah untuk mengetahui efektifitas penggunaan trainer pneumatik hasil pengembangan sebagai media pembelajaran pada materi pengontrolan gerak sekuensial dibandingkan dengan penggunaan training kit pneumatik. Hasil penelitian ini akan bermanfaat sebagai informasi penting untuk mengembangkan trainer pneumatik, sehingga 
pada akhirnya akan dihasilkan trainer pneumatik yang efektif sebagai media belajar.

Media mengajar merupakan segala macam bentuk perangsang dan alat yang disediakan fasilitator pengajaran untuk mendorong peserta pengajaran belajar. Perumusan ini menggambarkan pengertian media yang cukup luas, mencakup berbagai bentuk perangsang belajar, serta berbagai bentuk alat penyaji perangsang belajar, berupa alat-alat elektronika seperti mesin pengajaran, film, audio cassete, video cassete, televisi, dan komputer.

Mengutip pendapat Rowntree, Syaodih, N.S (2000: 108 - 109) mengelompok-kan media mengajar menjadi lima macam dan disebut Modes, meliputi : interaksi insani, realita, pictorial, simbol tertulis, dan rekaman suara.

a. Interaksi insani. Media ini merupakan komunikasi langsung antara dua orang atau lebih. Interaksi insani dapat berlangsung melalui komunikasi verbal maupun non verbal. Komunikasi verbal berperan terutama dalam perkembangan segi kognitif siswa, sedangkan komunikasi non verbal berperan dalam perkembangan segi afektif.

b. Realita. Ralita merupakan bentuk perangsang nyata seperti orang-orang, binatang, benda-benda, peristiwa, dan sebagianya yang diamati siswa.

c. Pictorial. Media ini menunjukkan penyajian berbagai bentuk variasi gambar dan diagram nyata ataupun simbol, bergerak atau tidak, dibuat di atas kertas, film, kaset, disket, dan media lainnya. Media pictorial mempunyai banyak keuntungan karena hampir semua bentuk, ukuran, kecepatan, benda , makluk , dan peristiwa dapat disajikan dalam media ini.

d. Simbol tertulis. Simbol tertulis merupakan media penyaji informasi yang paling umum, tetapi tetap efektif. Ada beberapa macam bentuk media simbol tertulis seperti buku teks, buku paket, paket program belajar, modul, dan majalah-majalah.

e. Rekaman suara. Rekaman suara dapat disajikan tersendiri atau digabung dengan media pictorial. Penggunaan rekaman suara tanpa gambar dalam pengajaran cukup efektif.

Sementara itu Dale, mengemukakan 12 media mengajar atau audio visual aid, yang disebutnya Cone of Experience, atau kerucut pengalaman. Urutan media 
tersebut mulai dari yang abstrak sampai pada yang kongkret, dengan urutan sebagai berikut : (1) verbal symbol, (2) visual symbols, (3) signs, stick figures, (4) radio \& recording, (5) still pictures, (6) educational television, (7) exhibits, (8) study trips, (9) demonstrations, (10) dramatized experiences ; plays, puppets, role playing, (11) contrived experience: models, mock ups, simulation, dan (12) direct purposeful experience.

Berdasarkan kerucut pengalaman tersebut terlihat hubungan antara jenis media belajar dengan pengalaman belajar. Media belajar yang semakin mendekati bentuk kongret akan meningkatkan pengalaman belajar. Dengan demikian pengembangan media pembelajaran harus diupayakan mendekati bentuk kongret agar pengalaman belajar semakin meningkat pula. Salah satu indikator peningkatan pengalaman belajar adalah minimalnya miskonsepsi peserta didik terhadap materi subjek.

Pengembangan media pembelajaran bidang pneumatik dari waktu ke waktu terus mengalami peningkatan. Bentuk media pembelajaran yang paling sederhana berupa simbol-simbol tertulis yang terstandar sesuai DIN ISO 1219 (Fluid power system and components; graphic symbol) dan DIN ISO 5599 (Pneumatic fluid power; 5-port directional control valve mounting surface; general). Pengembangan media untuk menjelaskan konsep mekanisme komponen selengkapnya mengikuti urutan sebagai berikut : (1) dimulai dari suatu simbol, (2) dibuat dalam bentuk gambar kerja komponen, (3) dibuat gambar animasi 2D, (4) dibuat prototip 2D gerak manual, (5) dibuat model animasi 3D, (6) dibuat prototip 3D gerak manual, (7) menggunakan produk asli.

Sementara itu, media pembelajaran yang dikembangkan untuk menjelaskan konsep struktur sistem, mempunyai tahapan sebagai berikut.

1. Media berupa simbol-simbol verbal langsung digambar/ditulis di papan tulis, kemudian ditarik garis penghubung antar saluran secara manual. Penjelasan cara kerja sistem dilakukan secara lisan.

2. Media berupa simbol-simbol dibuat modelnya dari bahan plastik/kertas yang bagian belakangnya dilengkapi magnet. Media ditempelkan pada papan bermagnet. Garis saluran ditarik digambar secara manual. Penjelasan cara kerja 
sistem dilakukan dengan menggeser simbol-simbol tersebut sesuai dengan posisi yang terjadi.

3. Media menggunakan komputer. Simbol-simbol disimpan dalam menu library. Untuk menggunakannya cukup dengan mengkopi simbol-simbol dari library tersebut. Garis saluran tergambar secara otomatis dengan menandai ujungujung saluran yang akan dihubungkan. Penjelasan cara kerja dilakukan oleh komputer melalui simulasi dalam bentuk animasi. Contoh jenis media ini adalah Fluid SIM-P yang dibuat oleh Festo seperti pada Gambar 1.
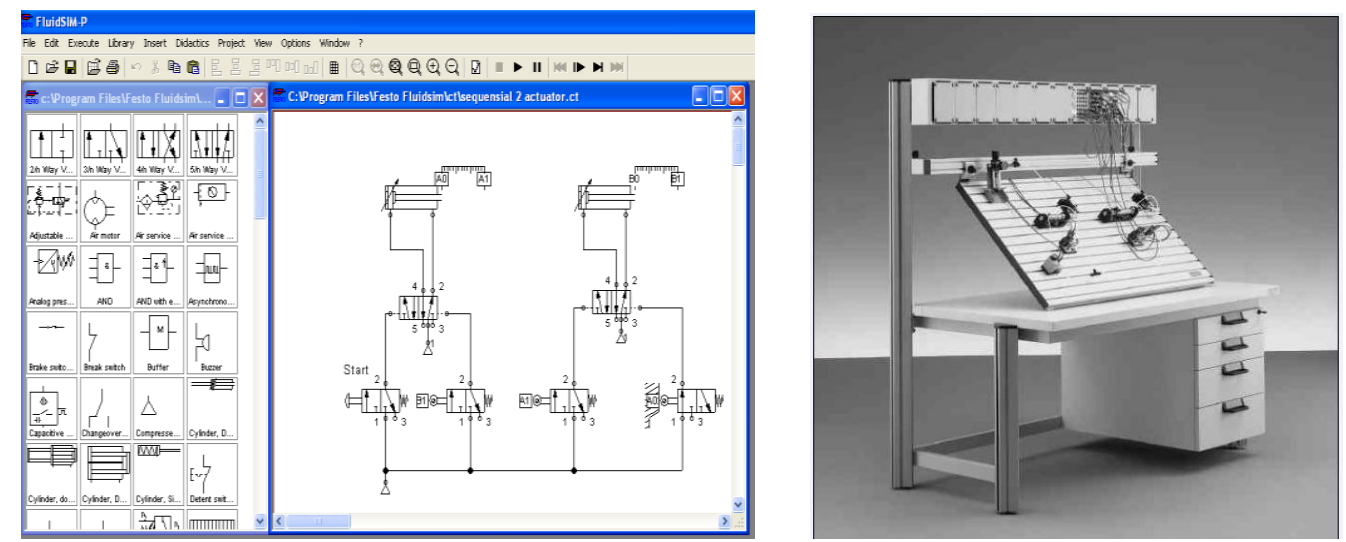

Gambar 1. Tampilan Fluid SIM-P dan training kit pneumatik

4. Media berupa training kit. Media in menggunakan benda berupa komponenkomponen pneumatik asli yang diletakkan pada sebuah profile plate yang berlubang. Bentuk profile plate dan sistem mounting komponen kemudian dikembangkan seperti gambar di bawah ini (http://www.festo-didactic.com/inten/training-and-consulting/ trainings/technology/). Simulasi kerja sistem secara langsung dapat diamati.

Media pembelajaran nomor 1 sampai dengan nomor 3 cocok untuk pembelajaran teori yang mengutamakan penguasaan materi pada aspek kognitif, tetapi kurang mampu memberi pengalaman dalam aspek psikomotor terutama berkaitan dengan kondisi nyata di industri. Pada media training kit, media ini cukup komprehensip untuk pembelajaran sistem pneumatik, meskipun berdasarkan analisis terdapat kekurangan, diantaranya adalah kurang portable, memerlukan waktu yang relatif lama, tidak langsung menunjukkan posisi sensor yang sebenarnya, dan sebagainya. 
Berdasarkan uraian tentang media belajar diatas dapat dibuat sebuah rumusan tentang pentingnya media belajar dikaitkan dengan pengembangan strategi pembelajaran. Pada hakekatnya strategi pembelajaran merupakan tindakan nyata dari penyampaian materi dan media pembelajaran merupakan salah satu sarana untuk menjadikan penyampaian materi itu lebih efektif dan effisien. Melalui penelitian sebelumnya telah dibuat sebuah media belajar berupa trainer pneumatic control system. Bentuk media yang dipilih berupa trainer, dimana media ini masuk dalam kelompok "Realita" atau mendekati "direct purposeful experience".

\section{METODE}

Penelitian ini menggunakan metode quasi-eksperimen dengan pre and post test design. Sebelum materi tentang pengontrolan gerak sekuensial diberikan, kepada responden pada kedua kelas (kelas eksperimen dan kelas control) dilakukan tes (pre test) berupa tes essay merancang sistem kontrol pneumatik gerak sekuensial dua aktuator yang diaplikasikan pada alat pemindah benda produk elektroplating. Kemudian pada saat penyampaian materi, sebagai media pembelajaran pada kelas eksperimen digunakan media trainer pneumatik hasil pengembangan sementara pada kelas kontrol digunakan media training kit pneumatic. Setelah pembelajaran selesai, pada kedua kelas dilakukan post test. Berdasarkan nilai pre test dan post test pada kedua kelas tersebut dapat disimpulkan tentang efektifitas media trainer pneumatik yang dikembangkan.

Desain trainer pneumatik yang digunakan dan sketsa alat pemindah benda sebagai bahan tes ditunjukkan pada Gambar 2.
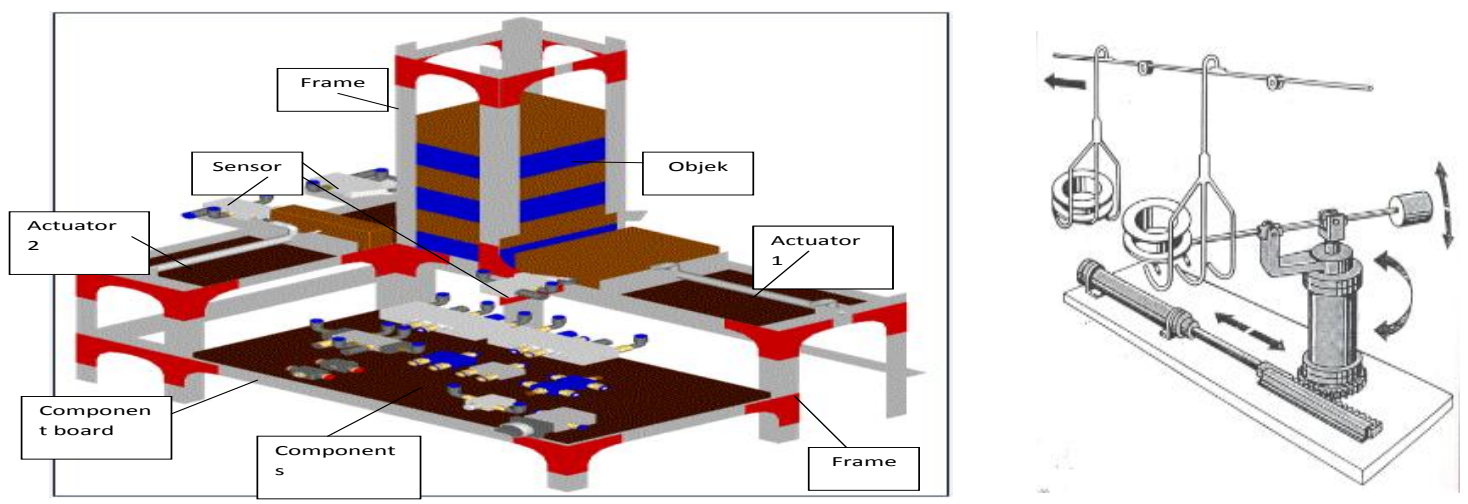

Gambar 2. Desain trainer pneumatic dan sketsa alat pemindah produk 


\section{HASIL PENELITIAN}

Pre test digunakan untuk mengetahui kemampuan awal responden pada kelas kontrol dan kelas eksperimen, sedangkan post test digunakan untuk mengetahui kemampuan responden setelah diberikan perlakuan. Data pre test, post test, dan perhitungan $\mathrm{N}$-gain ditunjukkan pada tabel 1.

Tabel 1. Skor pre test, post test dan $\mathrm{N}$-gain

\begin{tabular}{ccccccccc}
\hline & \multicolumn{3}{c}{ Pre test } & \multicolumn{3}{c}{ Post test } & \multicolumn{2}{c}{ N-gain } \\
\hline \hline & $\begin{array}{c}\text { Skor } \\
\text { Tertinggi }\end{array}$ & $\begin{array}{c}\text { Skor } \\
\text { Terendah }\end{array}$ & $\begin{array}{c}\text { Rata- } \\
\text { rata }\end{array}$ & $\begin{array}{c}\text { Skor } \\
\text { Tertinggi }\end{array}$ & $\begin{array}{c}\text { Skor } \\
\text { Terendah }\end{array}$ & $\begin{array}{c}\text { Rata- } \\
\text { rata }\end{array}$ & $\begin{array}{c}\text { Rata- } \\
\text { rata }\end{array}$ & $\begin{array}{c}\text { Varians } \\
\left(\mathrm{S}^{2}\right)\end{array}$ \\
\hline \hline Eksperimen & 83,4 & 7,9 & 36,4 & 91,7 & 30,6 & 66,4 & 0,44 & 0,1521 \\
\hline \hline Kontrol & 85,3 & 8,4 & 33,7 & 94,5 & 7,5 & 66,0 & 0,44 & 0,1225 \\
\hline
\end{tabular}

Rangkuman hasil pengujian statistik ditunjukkan pada tabel 2.

Tabel 2. Hasil pengujian statistik

\begin{tabular}{|c|c|c|c|c|c|c|}
\hline \multirow{2}{*}{ Data } & \multicolumn{2}{|c|}{ Uji Homogenitas } & \multicolumn{2}{|c|}{ Uji Normalitas } & \multicolumn{2}{|c|}{ Uji Hipotesis } \\
\hline & P-Value & Kondisi & P-Value & Kondisi & Nilai t & Kondisi \\
\hline Pretes & $\begin{array}{c}0,095>\alpha \\
0,05\end{array}$ & $\begin{array}{c}\text { Dua kelas } \\
\text { homogen }\end{array}$ & & & & \\
\hline \multirow[b]{2}{*}{ Postes } & \multirow{2}{*}{$\begin{array}{c}0,092>\alpha \\
0,05\end{array}$} & \multirow{2}{*}{$\begin{array}{l}\text { Dua kelas } \\
\text { homogen }\end{array}$} & $0,4422>0,05$ & Normal & & \\
\hline & & & $0,0953>0,05$ & Normal & & \\
\hline \multirow[b]{2}{*}{ N-Gain } & \multirow{2}{*}{$\begin{array}{l}0,094>\alpha \\
0,05\end{array}$} & \multirow{2}{*}{$\begin{array}{l}\text { Dua kelas } \\
\text { homogen }\end{array}$} & $0,4183>0,05$ & Normal & \multirow{2}{*}{$\begin{array}{l}t_{\text {hitung }}=0<t_{\text {tabel }} \\
=1,675\end{array}$} & \multirow{2}{*}{$\begin{array}{l}\text { Ho } \\
\text { diterima } \\
\mathrm{H}_{\mathrm{A}} \text { ditolak }\end{array}$} \\
\hline & & & $0,3813>0,05$ & Normal & & \\
\hline
\end{tabular}

Berdasarkan hasil perhitungan, dapat dilihat bahwa rata-rata kemampuan awal responden pada kelas eksperimen lebih tinggi dibandingkan dengan kelas kontrol. Demikian pula hasil belajar responden setelah diberi perlakuan. Sementara itu N-gain rata-rata pada kelas eksperimen dan kelas kontrol sama yaitu 0,44 . Setelah dilakukan perhitungan dengan uji F, didapatkan hasil kedua kelas tersebut homogen pada taraf kesalahan $5 \%$. Hasil ini berada pada penerimaan Ho artinya pada hasil pre test, post test, dan $\mathrm{N}$-gain tidak terdapat perbedaan yang signifikan antara kedua kelas tersebut.

Melalui pengujian dengan uji t pada $\mathrm{N}$-Gain didapat nilai $\mathrm{t}_{\text {hitung }}=0,0$ untuk $\mathrm{dk}=50$ diperoleh $\mathrm{t}_{\text {tabel }}=1,675$ karena $\mathrm{t}_{\text {hitung }}<\mathrm{t}_{\text {tabel }}$, maka Ho diterima dan $\mathrm{H}_{\mathrm{A}}$ ditolak, artinya tidak ada perbedaan hasil belajar antara responden yang 
menggunakan media trainer pneumatik dibandingkan dengan responden yang menggunakan media training kit.

\section{PEMBAHASAN}

Trainer pneumatik dirancang sebagai media/alat bantu bertujuan untuk meningkatkan pemahaman tentang rancangan sistem kontrol pneumatik. Untuk merangkai sistem kontrol pneumatik gerak sekuensial cukup sulit untuk dipelajari secara teoritis tanpa sebuah simulasi, seperti diungkapkan Robert (Azis, 2006: 33) bahwa model simulasi pada dasarnya merupakan salah satu strategi pembelajaran yang bertujuan memberikan pengalaman belajar yang lebih konkrit melalui tiruantiruan bentuk pengalaman yang mendekati suasana sebenarnya. Hal ini sejalan dengan pendapat Arsyad (2005: 10) yang menyatakan bahwa "hasil belajar seseorang diperoleh dari pengalaman langsung (konkret), kenyataan yang ada di lingkungan seseorang kemudian melalui benda tiruan, sampai kepada lambang verbal (abstrak)".

Trainer pneumatik merupakan alat yang terbuat dari beberapa komponen pneumatik asli dengan media udara bertekanan untuk mensimulasikan sistem kerja pneumatik. Kesulitan memahami rangkaian aplikasi sistem kontrol pneumatik akan berimplikasi pada kesalahan dalam merancang sistem kontrol, mengidentifikasi, memilih, dan merangkai komponen-komponen pneumatik untuk membentuk sebuah sistem kontrol dan sistem kerja.

Untuk merangkai sistem kontrol pneumatik gerak sekuensial cukup sulit untuk dipelajari secara teoritis tanpa sebuah simulasi, seperti diungkapkan Robert (Azis, 2006: 33) bahwa model simulasi pada dasarnya merupakan salah satu strategi pembelajaran yang bertujuan memberikan pengalaman belajar yang lebih konkrit melalui tiruan-tiruan bentuk pengalaman yang mendekati suasana sebenarnya. Hal ini sejalan dengan pendapat Arsyad (2005: 10) yang menyatakan bahwa "hasil belajar seseorang diperoleh dari pengalaman langsung (konkret), kenyataan yang ada dilingkungan seseorang kemudian melalui benda tiruan, sampai kepada lambang verbal (abstrak)”.

Pengalaman belajar mahasiswa sebelum mengalami proses belajar dapat terukur melalui tes awal (pretest). Skor tes awal menunjukkan tingkat penguasaan 
awal mahasiswa. Berdasarkan data distribusi frekuensi tampak berbentuk agak mendekati bentuk kurva normal, dimana sebagian terbesar dari mahasiswa memperoleh skor dibawah rata-rata sehingga dalam kurva akan menjuling positif karena ekornya di kanan. Setelah dilakukan perlakuan (treatment) dalam proses belajar mengajar dan dilakukan uji postest, menunjukkan rata-rata hasil belajar mahasiswa secara keseluruhan mengalami peningkatan, tetapi jumlah mahasiswa yang memperoleh nilai di atas rata-rata dengan mahasiswa yang memperoleh nilai di bawah rata-rata tidak terlalu jauh.

Berdasarkan kriteria efektivitas, Gibson dan kawan-kawan yang dikutip oleh Siagian SP (1988:25), dalam organisasi kepemimpinan dan perilaku administrasi, mengemukakan empat aspek yang dapat digunakan sebagai kriteria efektivitas yaitu: produksi, efesien, kemampuan adaptasi, dan pengembangan organisasi.

Produksi adalah kemampuan orgnisasi yang menghasilkan "Out Put” yang dibutuhkan oleh lingkungan. Pengertian produk dalam hal ini mencakup jumlah (kuantitas) dan mutu (kualitas) dalam bentuk nyata, produk tersebut dapat berupa lulusan yang dihasilkan sebuah Universitas.

Efesien menunjukkan pada pengukuran yang berkenaan dengan penggunaan sumber oleh organisasi yang merupakan pertandingan antara "Out Put" dan "Input". Dalam bentuk yang nyata efesien dapat dilihat dari besarnya biaya waktu yang diperlukan untuk suatu proses pendidikan (Universitas).

Kemampuan adaptasi adalah kesanggupan organisasi dalam melakukan perubahan sesuai dengan tuntutan keadaan. Penyebab, dilakukan perbahan dapat berasal dari luar (lingkungan) dan dapat pula dari dalam organisasi yang bersangkutan. Kondisi organisasi yang tidak produktif, tidak efesien atau tingkat kepuasan yang rendah bisa juga merupakan pertanda bahwa tindakan adaptasi perlu dilakukan. Adaptasi pada dasarnya merupakan respon terhadap situasi yang dihadapi, oleh karena itu kegiatan adaptasi baru nampak setelah situasinya menuntut untuk itu. Jika organisasi mampu dan tanggap melakukan penyesuaian dengan baik, maka dapat disimpulkan bahwa kemampuan adaptasi tersebut tinggi dengan kata lain organisasi yang bersangkutan cukup efektif ditinjau dari kriteria kemampuan adaptasinya. 
Pengembangan organisasi adalah kriteria efektifitas yang menunjukkan kemampuan organisasi untuk memandang jauh ke depan dalam melakukan investasi dalam rangka mempertahankan hidup dalam mengembangkan usaha organisasi. Kriteria pengembangan lebih menekankan kepada upaya organisasi dalam jangka panjang.

Sedangkan berdasarkan teori indikator efektivitas menurut Saliman dan Sudarsono (dalam Anisah, 1995: 33) mengatakan sebagai berikut:

1) Indikator input: meliputi karakteristik dosen, karakteristik fasilitas, karakteristik perlengkapa, materi pendidikan, dan kapasitas administrasi.

2) Indikator proses: meliputi perilaku administrasi, alokasi waktu dosen, serta alokasi waktu mahasiswa.

3) Indikator Out put: meliputi hasil-hasil dalam bentuk perolehan mahasiswa dan dinamikanya, sistem Universitas, hasil-hasil yang berhubungan dengan perubahan sikap, dan hasil-hasil yang berhubungan dengan keadilan dan kesamaan.

4) Indikator Out come: meliputi jumlah lulusan, hasil belajar yang lebih tinggi.

Berdasarkan analisis hasil penelitian, penulis dapat menyimpulkan bagaimana efektifvitas penggunaan trainer pneumatik sebagai media belajar mata kuliah Otomasi. Efektivitas penggunaan trainer pneumatik sebagai media belajar mata kuliah Otomasi dapat dilihat berdasarkan indikator efektivitas. Pertama, indikator input: meliputi karakteristik perlengkapan, fasilitas. Trainer pneumatik memiliki karakteristik: (1) Fleksibel, artinya menyediakan berbagai modul dasar yang dapat dirangkai dengan mudah untuk konfigurasi sistem. Modul dasar ini berupa komponen-komponen pneumatik yang mudah ditempatkan dan dirangkai untuk membentuk sebuah sistem kerja. (2) tingkat tinggi: tanpa pemprograman sama sekali.

Kedua, indikator proses: meliputi alokasi waktu. Waktu yang dibutuhkan lebih cepat dalam merangkai trainer pneumatik menjadi sistem kerja. Hal ini dikarenakan mahasiswa hanya melalui dua tahapan yaitu menyambungkan saluran pada setiap komponen pneumatik dan di uji coba.

Ketiga, indikator out put: meliputi hasil belajar. Rata-rata hasil belajar mahasiswa yang menggunakan media trainer pneumatik berada pada kriteria sedang. Hal ini mahasiswa yang memperoleh diatas nilai rata-rata dengan mahasiswa yang memperoleh dibawah nilai rata-rata tidak terlalu jauh. 
Keempat, indikator out come: meliputi jumlah lulusan. Jumlah mahasiswa yang menggunakan media trainer pneumatik yang memenuhi kriteria kelulusan mencapai $54 \%$ (14 dari 26 mahasiswa)

Dari empat indikator diatas, dapat disimpulkan bahwa penggunaan trainer pneumatik sebagai media pembelajaran dinilai cukup efektif. Implikasinya, bahwa trainer pneumatik hasil pengembangan tersebut dapat digunakan sebagai media belajar alternatif pada mata kuliah Otomasi khususnya pada materi perancangan kontrol gerak sekuensial yaitu untuk meningkatkan hasil belajar mahasiswa selain media training kit pneumatik yang sebelumnya digunakan.

Tidak adanya perbedaan hasil belajar antara kelas yang menggunakan media trainer pneumatik dengan kelas yang menggunakan media training kit pneumatik, mengindikasikan bahwa kedua media mempunyai efektifitas yang relatif sama sebagai media pembelajaran. Hal ini didukung pula oleh data rata-rata skor N-Gain pada kelas eksperimen dan kelas kontrol yang berada pada klasifikasi sedang, sehingga kedua media yang digunakan tersebut dinyatakan cukup efektif. Namun demikian bila dilihat dari efisiensi waktu yang digunakan, ternyata trainer pneumatik lebih effisien. Hal ini dimungkinkan karena dalam penggunaannya, siswa hanya tinggal menghubungkan saluran-saluran pada komponen sesuai dengan rancangan sirkuit diagram yang telah dibuat, sedangkan jika menggunakan training kit siswa harus memilih komponen, memasangnya pada tabel, baru kemudian merangkainya.

\section{KESIMPULAN}

Kesimpulan yang diperoleh dari penelitian ini adalah:

1. Rata-rata hasil belajar responden pada kedua kelas dalam kategori sedang

2. Media trainer pneumatik dan training kit pneumatik cukup efektif sebagai media pembelajaran pada materi perancangan kontrol gerak sekuensial.

3. Media trainer pneumatik yang dikembangkan tidak lebih efektif dari training kit pneumatik sebagai media belajar pengontrolan gerak sekuensial. 


\section{DAFTAR PUSTAKA}

Anthony, E. (1999). Fluid Power with Aplication, $2^{\text {nd }}$ edition, New York : Prentice Hill International.

H. Meixner. (1979). Introduction to Pneumatic, D-7300 Esslingen : Festo Didactic , 1977. Maintenance of Pneumatic, D-7300 Eslingen : Festo Didactic

, 1977. Maintenance of Pneumatic Equipment and System, D-7300 Eslingen : Festo Didactic.

Isdwiyanudi, S. (1996). Praktek Sistem Kontrol Pneumatik, Bandung : Pusat Pengembangan Pendidikan Politeknik Direktorat Jenderal Pendidikan Tinggi Departemen Pendidikan dan Kebudayaan

Nana Syaodih Sukmadinata. (2000). Pengembangan Kurikulum Teori dan Praktek , Bandung : PT Remaja Rosdakarya.

P. Croser (1989). Pneumatic Basic Level TP 101, D-7300 Esslingen : Festo Didactic

Patient, P. (1985). Pengantar Ilmu Teknik Pneumatika, Jakarta : PT Gramedia

Purnawan. (2006). Desain Model Komponen Pneumatik untuk Media Pembelajaran Mekanisme Komponen Pneumatik, Jurnal INVOTEC Volume III, No. 9, Agustus $2006: 116-124$.

Soenarto. (2005). Metodologi Penelitian Pengembangan untuk Peningkatan Kualitas Pembelajaran. Makalah pada Pelatihan Nasional PPKP dan PTK, bagi dosen LPTK di Pualu Batam dan Depasar. Departemen Pendidikan Nasional.

http://www.festo-didactic.com/int-en/training-andconsulting/trainings/technology/ diakses 17 Februari 2009 Pk 10:24 